\title{
Composting, anaerobic digestion and biochar production in Ghana. Environmental-economic assessment in the context of voluntary carbon markets
}

\author{
Pietro Galgani ${ }^{\text {a,* }}$, Ester van der Voet $^{\mathrm{a}}$, Gijsbert Korevaar $^{\mathrm{b}}$ \\ ${ }^{a}$ Department of Industrial Ecology, Institute of Environmental Sciences, Leiden University, Van Steenis gebouw, Einsteinweg 2, 2333CC Leiden, The Netherlands \\ ${ }^{\mathrm{b}}$ Department of Energy and Industry, Faculty of Technology, Policy, and Management, Delft University of Technology, Jaffalaan 5, 2628 BX Delft, The Netherlands
}

\section{A R T I C L E I N F O}

\section{Article history:}

Received 13 February 2014

Accepted 29 July 2014

Available online 6 September 2014

\section{Keywords:}

Composting

Anaerobic digestion

Biochar

Life cycle assessment

Carbon markets

Sub Saharan Africa

\begin{abstract}
A B S T R A C T
In some areas of Sub-Saharan Africa appropriate organic waste management technology could address development issues such as soil degradation, unemployment and energy scarcity, while at the same time reducing emissions of greenhouse gases. This paper investigates the role that carbon markets could have in facilitating the implementation of composting, anaerobic digestion and biochar production, in the city of Tamale, in the North of Ghana. Through a life cycle assessment of implementation scenarios for lowtech, small scale variants of the above mentioned three technologies, the potential contribution they could give to climate change mitigation was assessed. Furthermore an economic assessment was carried out to study their viability and the impact thereon of accessing carbon markets. It was found that substantial climate benefits can be achieved by avoiding landfilling of organic waste, producing electricity and substituting the use of chemical fertilizer. Biochar production could result in a net carbon sequestration. These technologies were however found not to be economically viable without external subsidies, and access to carbon markets at the considered carbon price of $7 \mathrm{EUR} /$ ton of carbon would not change the situation significantly. Carbon markets could help the realization of the considered composting and anaerobic digestion systems only if the carbon price will rise above 75-84 EUR/t of carbon (respectively for anaerobic digestion and composting). Biochar production could achieve large climate benefits and, if approved as a land based climate mitigation mechanism in carbon markets, it would become economically viable at the lower carbon price of $30 \mathrm{EUR} / \mathrm{t}$ of carbon.
\end{abstract}

(c) 2014 Elsevier Ltd. All rights reserved.

\section{Introduction}

This paper presents a research into the economic viability of composting, biochar production and anaerobic digestion (AD) in an African context. Organic waste can be a resource for energy production, nutrient recycling and soil restoration. However it is also a source of greenhouse gases (GHG) harmful to the global climate, if left to decompose anaerobically in non sanitary landfills. In Sub Saharan Africa the decomposition of organic waste in open landfills is estimated to be responsible for $6.8 \%$ of Africa's GHG emissions, and expected to keep rising with the economic development of the region, although various technologies can be used to process organic waste and reduce these emissions (Barton et al., 2008; Couth and Trois, 2010a). This paper discusses the environmental

\footnotetext{
* Corresponding author. Present address: Ecowijs, Nieuwelaan 48, 2611RS Delft, The Netherlands. Tel.: +31 (0)62 317 8020; fax: +31 (0)71 5277434 .

E-mail address: p.galgani@hotmail.com (P. Galgani).
}

impacts of three organic waste management systems and their benefits from a life cycle perspective. Furthermore it aims at evaluating how the access to finance from carbon trading can support their implementation. The research is based on a case study from the peri-urban area of the rapidly growing city of Tamale in Ghana, an area where soil degradation is a major development issue (Al-Hassan and Poulton, 2009; Alfsen et al., 1997; Cofie et al., 2009; Derbile, 2010; Quaye, 2008; Songsore, 1996) and energy scarcity leads to daily blackouts.

\subsection{Composting and AD for sustainable MSW management}

Most of the research on waste management in Sub Saharan Africa advocates composting as an appropriate technology for management of the organic fraction of municipal solid waste (MSW) in Africa, for its GHG abatement potential, low technical complexity and low capital requirements (Barton et al., 2008; Couth and Trois, 2010b; Couth and Trois, 2012). AD is also 
considered a particularly suited technology for the African context for the same reasons (Boyd, 2012; Mohammed et al., 2013a). Furthermore composting has been identified as an especially beneficial solution for the North of Ghana, where Tamale is located, because of its potential contribution to nutrient cycling (Cofie et al., 2009; Drechsel and Kunze, 2001) and soil restoration (Blench, 2007; Derbile, 2010) and many have suggested AD as a feasible renewable energy technology with high GHG abatement potential in Ghana (Arthur et al., 2011; Mohammed et al., 2013b; Ofori-Boateng et al., 2013; Wikner, 2009).

However the real benefits for climate change mitigation of these technologies must be evaluated from a life cycle perspective, looking at indirect impacts caused by their implementation in a pre-determined geographical context. The net GHG abatement potential of composting and AD has in fact been found to be influenced to a large extent by site specific factors like transportation distances (Lundie and Peters, 2005; Peters and Rowley, 2009), final use of the compost (Boldrin et al., 2009; Couth and Trois, 2012a), alternative sources of energy (Friedrich and Trois, 2011; Sonesson et al., 2000) and process energy use and process emissions (Butler and Hooper, 2010; Edelmann et al., 2000; Peters and Rowley, 2009). Just a handful of studies nonetheless assess the benefits for GHG abatement of composting and AD referring specifically to the context of developing countries (Aye and Widjaya, 2006; Barton et al., 2008; Boyd, 2012; Friedrich and Trois, 2011, 2013; Nzila et al., 2012; Salum and Hodes, 2009). No Ghanaian case study has been found in peer-reviewed literature, although in gray literature Wikner (2009) does provide an extensive GHG footprint of alternative waste management options for the city of Kumasi in Ghana. Following the indication by Barton et al. (2008) and Friedrich and Trois (2011) that more studies are required to evaluate these benefits in specific African urban areas, this paper aims to quantify GHG reductions from composting and $\mathrm{AD}$ in Ghana and specifically in Tamale.

The economic viability of these two technologies varies according to local conditions, too, i.e. land cost, distances to be covered by waste and fertilizer transportation, compost demand and electricity price. Different studies have found them to be viable in developing countries (Aye and Widjaya, 2006; Zurbrugg et al., 2002) or barely feasible, depending on revenues from carbon markets and feed-in tariffs (Couth and Trois, 2012b; Salum and Hodes, 2009). Danso et al. (2006) assessed the willingness of Ghanaian farmers in different cities to pay for compost from MSW and found that based on production and transport costs only farmers in the range of $35 \mathrm{~km}$ from a composting station would be able to benefit from it, and that the willingness to pay in Tamale was on average 10 times higher than in other Ghanaian cities. Nonetheless their research shows that compost production would require subsidies to be viable. To our knowledge no other study presents a detailed economic assessment of composting and/or AD in Ghana.

\subsection{Biochar production}

Biochar is another technology in the field of organic waste management that shows potential for agriculture and climate change mitigation. Biochar is charcoal, produced with pyrolysis of biomass. It is at the same time an extremely stable way of sequestering carbon and, in certain conditions, a powerful soil ameliorant (Lehmann et al., 2006; Woolf et al., 2010), so it could be a very effective way of using farmland as carbon sink, while at the same time improving its productivity.

The production of biochar was included in the environmental and economic assessment of organic waste management system in Tamale because of the high potential of biochar in tropical sandy acidic soils (Duku et al., 2011; Maraseni, 2010), like those of North- ern Ghana, and in order to evaluate whether co-producing biochar and compost, two organic soil amendments with the same market, could create economies of scale through logistic and management synergies and improve the economic performance of both. Biochar is already being tested in the region by NGOs reporting very positive impact on crop yields (Abokobi Society Switzerland, 2013).

Although pyrolysis is suited for producing energy and fuel from MSW (Li et al., 1999; Malkow, 2004; Yufeng et al., 2003) no literature sources have been found reporting agricultural tests of biochar produced from MSW. Only one study (Ibarrola et al., 2012) explored its GHG footprint with an LCA focused on the U.K. context. In this research biochar is therefore considered to be produced from rice husks, the currently unused waste of Tamale's rice mill, as many studies have suggested the technical feasibility and agricultural benefits of biochar production from this feedstock (Haefele et al., 2011; Islam and Ani, 2000; Lehmann et al., 2006; Ogawa and Okimori, 2010; Shackley et al., 2012a; Woolf et al., 2010). The only economic assessment of biochar focusing on the African context is found in Scholz et al. (2014), who analyzes two scenarios from Senegal and Kenya also from an LCA perspective. Sparrevik et al performed an LCA of biochar based in Zambia (2013) and another one based in Indonesia, together with a societal cost benefit analysis (2014). Shackley et al. (2012b) performed an economic and GHG assessment of biochar production from rice husks in Cambodia, while all other studies focus on industrialized countries (Field et al., 2013; Galinato et al., 2011; Gaunt and Lehmann, 2008; Ibarrola et al., 2012; Roberts et al., 2010). In general GHG balances of biochar systems show high potential for carbon sequestration, although the extent of the net benefit depends on a number of case-specific factors, such as considered baseline (Ibarrola et al., 2012; Roberts et al., 2010; Shackley et al., 2012b), type of feedstock used (Roberts et al., 2010) especially in developing countries, technology used (Field et al., 2013; Sparrevik et al., 2013). For biochar, even more than for composting and $\mathrm{AD}$, economic viability seem to require the access to revenues from the sales of carbon credits in developing (Pratt and Moran, 2010; Shackley et al., 2012b; Scholz et al., 2014) as much as developed countries (Field et al., 2013; Galinato et al., 2011; Roberts et al., 2010).

\subsection{Carbon markets and organic waste management}

Composting, AD and biochar production can abate GHG emissions in a number of ways: by avoiding methane formation in landfills, by producing renewable energy, by avoiding the use of mineral fertilizer and by sequestering carbon in agricultural soil, in the form of organic matter (organic carbon) or biochar (elemental, or black, carbon). Not all these benefits can however qualify to be financially rewarded by carbon trading mechanisms, as accounting methodologies have only been approved so far for the former two (UNFCCC, 2010, 2011). The inclusion of soil carbon sequestration in carbon trading is being advocated for by a part of the scientific community (Whitman and Lehmann, 2009; Woolf et al., 2010 for biochar, Lal, 2004; Ringius, 2002; Vagen et al., 2005 for organic soil carbon sequestration) and do exist in some specific carbon markets outside the CDM (American Carbon Registry, 2013; Australian DoE, 2013; Verified Carbon Standard, 2013). Nowhere to our best knowledge can carbon offsets be generated for recycling of nutrients by producing organic fertilizer from waste (Couth and Trois, 2012a). In this study, besides methane avoidance and renewable energy, the economic assessment also considers carbon credits for biochar sequestration. Biochar projects do not yet qualify for carbon crediting under any scheme, although the American Carbon Registry is currently working on a methodology for this kind of intervention (ACR, 2013). 


\section{System definition}

In the assessment the perspective of an organic waste operator active in Tamale is taken. The system investigated includes therefore the collection and processing of organic waste in the city of Tamale, the transportation and sale of organic fertilizer and biochar to the peri-urban and rural areas surrounding the city and the delivery of electricity to the grid. The use of the agricultural inputs is only partially modeled: their application into the soil is included in the GHG footprint but not in the economic analysis. The harvesting of crops is not modeled due to lack of data about yields of different crops with different input combinations and to the choice of adopting the perspective of a waste operator. Instead, the assumption is made that the organic fertilizer and biochar will increase the fertility of soils to some extent, and farmers will apply them based on their budget for inputs rather than their agronomic value. By limiting the modeling of farm processes the uncertainties about the actual interactions between biochar, compost and crop yields are excluded from the evaluation of the technologies, which is approached from a waste management and climate change mitigation perspective.

Three alternative scenarios have been compared. These scenarios have been defined based on the supply of organic waste and the demand for agricultural inputs in Tamale and surroundings, in collaboration with DeCo! Sustainable Farming (DeCo), a composting business active in Tamale since 2009. In all the scenarios MSW is composted together with other locally available organic inputs and then mixed with poultry manure, which is transported from the city of Kumasi, $370 \mathrm{~km}$ South of Tamale. This is a necessary step to optimize the quality of the finished organic fertilizer, as in Tamale no supply of such nutrient rich organic waste is readily available. AD and biochar production are not considered as alternatives to composting but are implemented alongside it (Fig. 1), in order to investigate the cost savings in terms of marketing, logistics and economies of scale that can be realized by combining these organic waste management technologies. AD of MSW is considered to take place before composting, while biochar is considered to be produced from rice husks, rather than MSW. Rice husks are both a common feedstock for biochar production (Scholz et al., 2014; Jirka and Tomlinson, 2014; Preston and Leng, 2013; Sujana et al., 2014), and one of the only waste flows from the agro-processing industry in Tamale. Biochar made from this feedstock is currently being tested in Tamale in combination with organic fertilizer (Ghanaweb, 2014).

COMPOST: in this scenario MSW from Tamale is delivered to a composting plant located in the outskirts of the city by the local waste operators, and then composted together with other locally available biomass. The finished compost is then mixed with dry

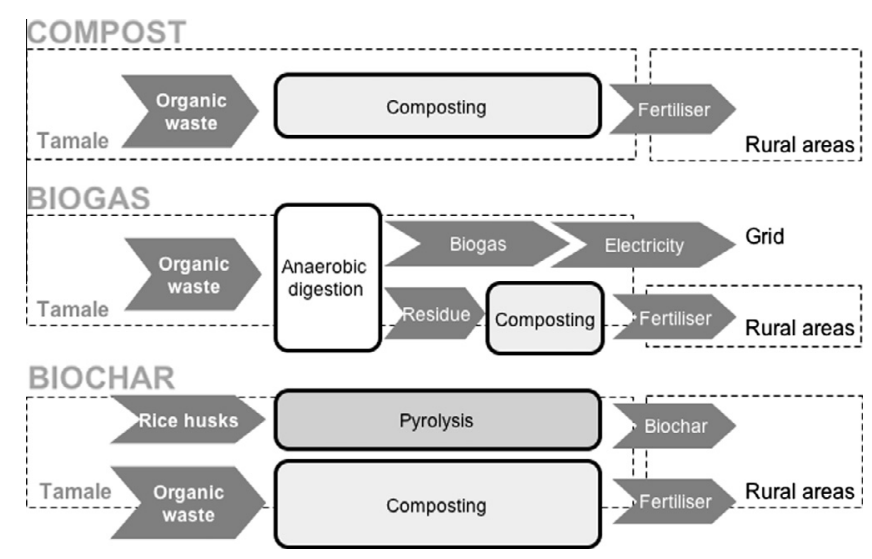

Fig. 1. System definition. The COMPOST system only includes composting, BIOGAS includes anaerobic digestion integrated with composting, BIOCHAR includes parallel pyrolysis composting systems. poultry manure to increase the nitrogen content of the fertilizer, and sold to farmers within a range of $50 \mathrm{~km}$ from the city, who use it to substitute or complement mineral fertilizer. This scenario is built based on the actual operations of DeCo in the region.

BIOGAS: This scenario is based on COMPOST, but the MSW delivered to the composting plant undergoes an additional processing step. The waste is digested in a dry fermentation reactor to produce biogas which is converted to electricity and sold to the grid. The digestion residue is composted together with other organic inputs and then sold in a range of $50 \mathrm{~km}$ from the plant as in COMPOST.

BIOCHAR: this scenario includes a pyrolysis system that produces biochar from the waste of the local rice mill alongside the composting system described in COMPOST. Rice husks are transported to the composting plant in the outskirts of the city, where biochar is produced. Compost and biochar are then marketed and sold together to farmers in a range of $50 \mathrm{~km}$ from the plant.

The scale of the system is defined as a plant with an output of 3000 tons of organic fertilizer. This kind of throughput requires an input of 1500 tons per year of organic fraction of MSW, and 3000 tons of other types of organic waste. For comparison, the MSW generated in Tamale in one year is about 295,000 tons, of which $40 \%$ organic, according to the best estimates available (Puopiel, 2010; Drechsel et al., 2004, Zoomlion Ghana Ltd., personal communication 28.06.2011). Biochar was considered to be produced from rice husks from the local rice mill, which can process up to 12,000 tons of rice per year (Braimah, 2011). The pyrolysis system was then assumed to process 2400 tons per year of rice husks, assuming rice husks generation is $20 \%$ of total rice production by the rice mill (following Karve and Prabhune, 2009).

\subsection{Technology description}

Low-tech and labor intensive technologies were considered, as more suited to the context of Sub Saharan Africa as they minimize capital costs, the risks of technical failures and energy demand, while maximizing job creation.

For composting windrow composting as used in Tamale since 2009 by DeCo was considered. DeCo made available data from its implementation experience in the city for this research. In this process the hand separated fraction of MSW is piled up in heaps $1.5 \mathrm{~m}$ tall, together with dry leaves and residues from the traditional shea butter industry, in proportion of $1 \mathrm{t}: 0.5 \mathrm{t}: 0.5 \mathrm{t}$. The composting process takes about 2 months to complete, during which the heap is periodically turned by hand and the feedstock loses $50 \%$ of its mass. At the end of the process the finished compost is mixed with the same amount of poultry manure. MSW constitute therefore only one third of total input by mass.

For anaerobic digestion a low cost dry fermentation reactor designed and piloted within a EAWAG-ETH Zurich project in Kumasi, Ghana is considered. The project made available technical and economic data for this research. The reactor is a shipping container fitted with a water percolation system where water is pumped from a tank, trickles down from the ceiling and is collected again on the bottom. Methane generated within the digester can be collected to fuel an electricity generator. One digester can process about 36 tons per year (Burri and Martius, 2011) and more digesters can be connected in series to scale up capacity. In dry fermentation the digestion residue is solid. This means that the digestate can be processed with windrow composting, while normally the residue from anaerobic digestion is liquid and cannot be further treated aerobically. Another advantage of this technology is the relatively low capital cost of $285 \mathrm{US} \$ / \mathrm{m}^{3}$, since according to existing reviews of AD in Ghana prices range between 235 and 500 US\$/ $\mathrm{m}^{3}$ (Bensah and Brew-Hammond, 2010; Bensah et al., 2011; Burri and Martius, 2011). 
Many possible ways exist to produce biochar, ranging from biomass cookstoves for households that have biochar as a byproduct to industrial pyrolysis installations that process tens of thousands of tonnes of organic materials per year for bioenergy generation. In this study we look at centralized production of biochar, from the 2400 tons of rice husks per year that constitute the waste of Tamale's rice mill. Since the details of no specific technology were available a hypothetical biochar oven is modeled. The system is assumed to be a simple slow pyrolysis batch reactor, or kiln, where rice husks are charred by being burned in absence of oxygen. Syngas, a mix of methane, carbon monoxide and other trace gases, is formed in a pyrolysis reaction and it is assumed to be recirculated into the oven to fuel the combustion reaction. The only product of the process is assumed to be biochar, because such a simple kiln is the pyrolysis technology more suited to a developing country (Sparrevik et al., 2013; Pratt and Moran, 2010), although producing energy together with biochar can also have interesting economics (as observed for example by Shackley et al., 2012b, for rice husks in Cambodia).

\section{GHG footprint}

\subsection{Baseline and functional unit}

The quantification of the climate benefits of implementing the considered systems was performed using LCA (Guinée, 2002) limited to climate change impacts.

The processes included in the inventory of each scenario are depicted in Fig. 2. Included in the systems are the transportation of waste to processing, the processing of organic waste, the delivery of fertilizer to the farms, emissions of nitrogen oxide $\left(\mathrm{N}_{2} \mathrm{O}\right)$ from agricultural land and carbon sequestration into soil, emissions from the construction of capital goods (composting plant, digesters, generator, pyrolysis oven, trucks) plus the travelling of the project's international staff. The pumping of water is not included because no data was available about either water consumption of studied technologies or energy consumption of water pumps.

Since the considered system fulfills several different functions, the functional unit was expanded to include waste treatment, production of fertilizer and electricity generation. It was defined as one year of project operation at the considered scale, which is the disposal of 1500 tons of organic fraction of MSW and of 2400 tons of rice husks, fertilization of 1250 hectares of land and production of 301.7 MW h of electricity. The amount of fertilized land was calculated assuming that the compost will be applied by all farmers at the same rate, that which is considered equivalent in terms of crop yields to the currently used rate of NPK fertilizer commonly used (SARI, 2011). Soil amendment with biochar was considered as a side benefit and excluded from the functional unit (as explained in Section 2 System definition).

A fourth scenario, BASELINE, was constructed to represent business as usual in the LCA. In BASELINE MSW is landfilled, energy is produced with a diesel generator, rice husks are incinerated. Since in the organic fertilizer produced by DeCo only $18 \%$ of the Nitrogen comes from the compost, while the remaining $82 \%$ comes from poultry manure (DeCo, unpublished data), in BASELINE $18 \%$ of farmers are considered to use NPK fertilizer, while the rest use poultry manure. The poultry manure in BASELINE is assumed to be used in Kumasi, where it is generated, rather than in Tamale (370 km distance).

\subsection{Life cycle inventory}

The main assumptions used in the LCA model can be found in Table 1 below. Primary data, collected in Tamale in 2011 and provided by DeCo, by the EAWAG-ETH Zurich AD pilot project, by the Savannah Agricultural Research Institute, and by interviews with the local waste operator was used for fuel consumption of local transportation, AD and composting yields, carbon and nitrogen content of compost and modeling of farming practices. The remaining data comes from the LCA database Ecoinvent (2010) or from literature as detailed below. Because of the lack of data and emission factors for the Ghanaian context, however, conservative values were assumed and an uncertainty analysis was performed (Section 3.3). Table 1 shows the assumed values used for the life cycle model and the ranges used for the uncertainty analysis.

In the model the 3000 tons of organic fertilizer are assumed to be sold in the three districts surrounding Tamale and delivered in equal quantities to 11 distribution points in the main urban centers, at an average distance of $37 \mathrm{~km}$. Waste from shea nut processing, constituting $25 \%$ of the feedstock for compost, is assumed to be sourced in the range of $20 \mathrm{~km}$, while the $25 \%$ of leaves was assumed to be collected locally without need for transportation. Poultry manure, constituting $50 \%$ of the final fertilizer, comes from Kumasi, about $370 \mathrm{~km}$ South of Tamale. The impact of transportation of NPK fertilizer was calculated assuming ship freight from Scandinavia (where the only fertilizer marketed in Tamale is manufactured, Yara Ghana, 2011) to the port of Tema in Ghana and then road transport to Tamale. Fuel consumption factors were calculated using data about actual fuel consumption by local garbage trucks ( $0.07 \mathrm{l}$ of diesel per ton-km, Zoomlion Ghana Ltd., personal communication 28.06.2011) and those used for transportation of organic fertilizer ( 0.041 of diesel per ton-km, Savannah Agricultural Research Institute, personal communication 22.06.2011). These values are high compared to those reported by others (Ecoinvent, 2010; Field et al., 2013; Hine and Sinaga, 2001), but they are considered consistent with the fact that vehicles used in West Africa are often old and inefficient, as also observed by Friedrich and Trois (2011, 2013). Backhaul trips were considered to consume $68 \%$ of full load trips (Woods and Cooper, 2006). Fertilizer made from composted digestate was assumed to have the same properties as composted waste. The increase of soil organic carbon caused by the use of organic fertilizer was included since it can be significant, although it is extremely dependent on soil characteristics, local climate, type of organic fertilizer used and farming practices (Vagen et al., 2005; Biala, 2011; Butler and Hooper, 2010), and therefore difficult to estimate accurately without direct measurements. Furthermore soil carbon accumulation dynamics are not linear (i.e. sequestration decreases with time, as a new equilibrium level of soil carbon is reached), while LCA is. Values of soil organic carbon accumulation over 20 years in the literature range from $2 \%$ to $14 \%$ of the carbon present in the fertilizer applied (Luske and Van der Kamp, 2009; Boldrin et al., 2009; Brown et al., 2008; Biala, 2011), so here a value of $8 \pm 6 \%$ was adopted. This is equivalent to $5 \mathrm{~kg}$ of carbon sequestered, or $17 \mathrm{~kg} \mathrm{CO}$ eq, per ton of compost applied to the soil. At the considered organic fertilizer application rates of $1 \mathrm{t} / \mathrm{ha}$, however, it is not sure whether soil carbon levels would increase or rather diminish less fast than they normally do. The effects on crop yield would be evident, due to the extreme carbon poverty of local soils, but the difference from business as usual would be too small to be measured by most instruments (Dr. Mathias Fosu, Savannah Agricultural Research Institute, 2011, personal communication 22.06.2011). Application rates for conventional NPK fertilizer were estimated together with the Savannah Agricultural Research Institute in Tamale to be $2 / 3$ of the rate recommended by the Ghanaian government. For organic fertilizer it was assumed that 1 ton can substitute 0.1 ton of NPK, following the results of field trials performed in the region (SARI, 2011). Most farming is done by hand in this region, thus without GHG emissions. The most common 

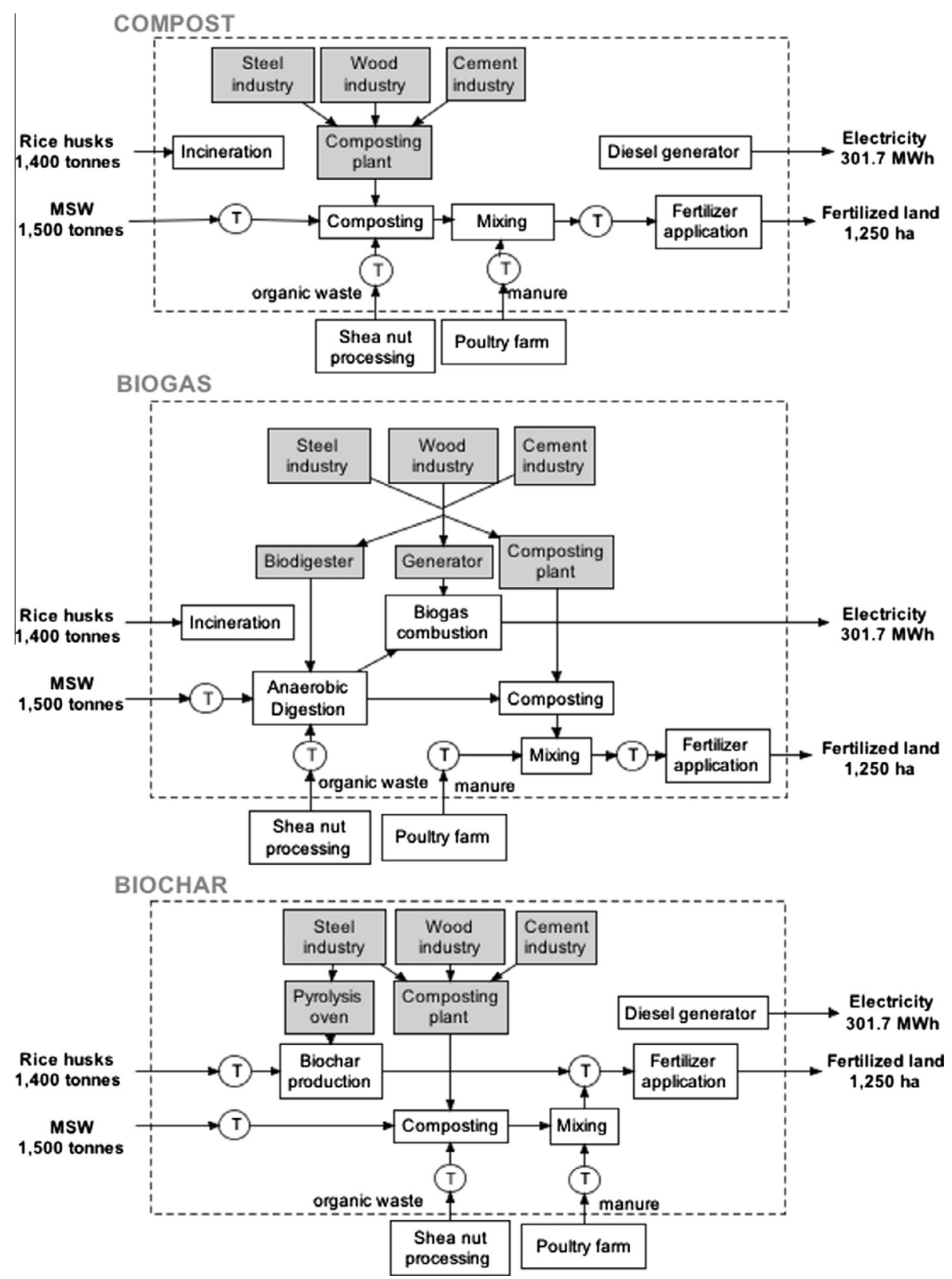

Fig. 2. System definition for LCA. $T=$ transportation. Gray boxes $=$ capital goods. White boxes = processes. Dashed line $=$ system boundaries. Bold text $=$ functional units.

mechanized process is ploughing, and it is not included in the LCA because assumed to be the same in all scenarios. The biogas yield of the digesters is assumed to be $100 \mathrm{~m}^{3} / \mathrm{t}$ waste, with a methane content of $60 \%$, the efficiency of the generator 0.35 (Burri and Martius, 2011). The amount of carbon in rice husks biochar ranges between 0.35 and $0.59 \mathrm{t} \mathrm{C/t}$ biochar (Woolf et al., 2010; Shackley et al., 2012a; Haefele et al., 2011) of which $80-92 \%$ is recalcitrant, the fraction which is permanent in soil (Shackley et al., 2012a; Woolf et al., 2010). Sequestered carbon can therefore range between 0.28 and $0.54 \mathrm{tC} / \mathrm{t}$ biochar, and here a value of $0.42 \pm 0.07$ was assumed. At the considered pyrolysis yield of $0.3 \pm 0.05 \mathrm{t}$ biochar/t rice husks, 720 tons of biochar are produced every year, which are applied to new land each year at a rate of $10 \mathrm{t} / \mathrm{ha}$. $\mathrm{N}_{2} \mathrm{O}$ emissions from farmland were estimated following IPCC recommendations (De Klein et al., 2006) and it was assumed that they would be $50 \%$ lower in land amended with biochar, following Woolf et al. (2010). Since every year biochar is applied to new land, the value of $\mathrm{N}_{2} \mathrm{O}$ emissions avoided will grow in the years, and it was here averaged over 20 years. GHG emissions from
NPK fertilizer manufacturing were calculated using the E-LCA software by CML (Van der Voet et al., 2008). Cement, steel and wood requirements for capital goods (waste processing equipment and vehicles) were estimated by the authors in collaboration with DeCo, and emission factors were taken from the Ecoinvent database (2010).

Table 2 shows the results of the impact assessment, broken down by life cycle steps.

BIOCHAR is the scenario with the lowest impact, a negative impact in fact, since the sequestration of carbon offsets all the emissions incurred in the rest of the system. BIOGAS is second best, thanks to the double climate benefits of avoiding landfilling and generating electricity, summing up to a 58\% total GHG emission reduction compared to BASELINE. The COMPOST scenario also brings significant benefits, with an emission reduction compared to BASELINE of $41 \%$.

The biggest benefit of the considered scenarios is in the waste processing stage, namely the avoidance of landfilling. Methane and nitrous oxide emissions from compost heaps are also an 
Table 1

LCA assumptions and sources.

\begin{tabular}{|c|c|c|c|c|c|}
\hline Process & Unit & $\begin{array}{l}\text { Values in } \\
\text { literature }\end{array}$ & Sources & $\begin{array}{l}\text { Considered } \\
\text { value }\end{array}$ & $\begin{array}{l}\text { Considered } \\
\text { uncertainty range }\end{array}$ \\
\hline $\begin{array}{l}\text { Methane generation from } \\
\text { landfill }\end{array}$ & $\mathrm{kg} / \mathrm{t}$ waste & $20-40$ & UNFCCC (2010) & 30 & $20-40$ \\
\hline $\begin{array}{l}\text { Methane losses from } \\
\text { composting }\end{array}$ & $\mathrm{kg} / \mathrm{t}$ waste & $0.004-8$ & De Groot (2010), Butler and Hooper (2010), Brown et al. (2008) & 4 & $0-8$ \\
\hline Methane losses from AD & $\mathrm{kg} / \mathrm{t}$ waste & $0-8$ & De Groot (2010) & 1 & $0-2$ \\
\hline $\begin{array}{l}\text { Methane losses from } \\
\text { pyrolysis }\end{array}$ & $\mathrm{kg} / \mathrm{t}$ waste & $6-13$. & Sparrevik et al. (2013) & negl. & $0-13$ \\
\hline $\begin{array}{l}\mathrm{N}_{2} \mathrm{O} \text { generation from } \\
\text { landfill }\end{array}$ & & negl. & Brown et al. (2008), UNFCCC (2010) & negl. & \\
\hline $\begin{array}{l}\mathrm{N}_{2} \mathrm{O} \text { generation from } \\
\text { composting }\end{array}$ & $\mathrm{g} / \mathrm{t}$ waste & $60-600$ & De Groot (2010), Brown et al. (2008) & 300 & $0-600$ \\
\hline $\mathrm{N}_{2} \mathrm{O}$ generation from $\mathrm{AD}$ & $\mathrm{g} / \mathrm{t}$ waste & $0-120$ & De Groot (2010) & negl. & \\
\hline $\begin{array}{l}\mathrm{N}_{2} \mathrm{O} \text { generation from } \\
\text { pyrolysis }\end{array}$ & $\mathrm{g} / \mathrm{t}$ waste & $0-4$ & Field et al. (2013), Sparrevik et al. (2013) & negl. & \\
\hline Compost yield & t/t waste & & DeCo & 0.5 & $0.4-0.6$ \\
\hline Methane yield from AD & $\mathrm{m}^{3} / \mathrm{t}$ waste & & Burri and Martius (2011) & 60 & $0.50-0.70$ \\
\hline Biochar yield & $\mathrm{t} / \mathrm{t}$ waste & $0.25-0.35$ & Field et al. (2013), Fournier (2009) & 0.30 & $0.25-0.35$ \\
\hline $\mathrm{C}$ content in compost & $\mathrm{t} \mathrm{C} / \mathrm{t}$ compost & & DeCo & 5.91 & \\
\hline $\begin{array}{l}\text { C content in poultry } \\
\text { manure }\end{array}$ & $\mathrm{t} \mathrm{C} / \mathrm{t}$ manure & & DeCo & 33.15 & \\
\hline $\mathrm{N}$ content in compost & $\mathrm{t} \mathrm{N} / \mathrm{t}$ compost & & DeCo & 0.57 & \\
\hline $\begin{array}{l}\mathrm{N} \text { content in poultry } \\
\text { manure }\end{array}$ & $\mathrm{t} \mathrm{N} / \mathrm{t}$ manure & & DeCo & 2.60 & \\
\hline $\begin{array}{l}\text { Organic fertilizer } \\
\text { application rate }\end{array}$ & t/ha & & DeCo & 2.4 & \\
\hline $\begin{array}{l}\text { NPK fertilizer application } \\
\text { rate }\end{array}$ & t/ha & & DeCo & 0.24 & \\
\hline Biochar application rate & t/ha & $0.4-41$ & Ogawa and Okimori (2010), Haefele et al. (2011), DeCo & 10 & \\
\hline $\begin{array}{r}\text { Biochar carbon } \\
\text { sequestered }\end{array}$ & $\mathrm{t} \mathrm{C} / \mathrm{t}$ biochar & $0.28-0.54$ & Woolf et al. (2010), Shackley et al. (2012a), Haefele et al. (2011) & 0.42 & $0.35-0.49$ \\
\hline Soil $\mathrm{N}_{2} \mathrm{O}$ emissions & $\%$ of $\mathrm{N}$ applied & & De Klein et al. (2006) & 0.016 & \\
\hline $\begin{array}{l}\text { Soil } \mathrm{N}_{2} \mathrm{O} \text { emissions } \\
\quad \text { reduction with biochar }\end{array}$ & $\begin{array}{l}\% \text { of } \mathrm{N}_{2} \mathrm{O} \\
\text { emissions }\end{array}$ & $50-80 \%$ & Woolf et al. (2010) & $50 \%$ & $20-80 \%$ \\
\hline $\begin{array}{l}\text { Soil organic carbon } \\
\text { sequestration }\end{array}$ & $\begin{array}{l}\% \text { of } C \text { in } \\
\text { organic } \\
\text { fertilizer }\end{array}$ & $2-14 \%$ & $\begin{array}{l}\text { Luske and Van der Kamp (2009), Boldrin et al. (2009), Brown et al. } \\
\text { (2008), Biala (2011) }\end{array}$ & $8 \%$ & $2-14 \%$ \\
\hline $\begin{array}{l}\text { Emission factor NPK } \\
\text { fertilizer production }\end{array}$ & $\begin{array}{l}\mathrm{kg} \mathrm{CO}_{2} \text { eq/ } \\
\mathrm{kg} \mathrm{NPK}\end{array}$ & & Ecoinvent (2010), Van der Voet et al. (2008) & 1.13 & \\
\hline $\begin{array}{l}\text { Truck transport emissions } \\
\quad \text { (Garbage truck) }\end{array}$ & $\mathrm{l} / \mathrm{t} \mathrm{km}$ & $\begin{array}{l}0.015-0.05 \\
(0.07)\end{array}$ & $\begin{array}{l}\text { Ecoinvent (2010), Field et al. (2013), Hine and Sinaga (2001), } \\
\text { Friedrich and Trois (2013) (Zoomlion Ghana Ltd.) }\end{array}$ & $0.04(0.07)$ & $0-03-0.05$ \\
\hline
\end{tabular}

important impact, as well as poultry manure transport in COMPOST, BIOGAS and BIOCHAR alike, while other transport impact account for less than $1 \%$ of impacts in all scenarios. The avoided production of NPK fertilizer accounts for $4-10 \%$ of the total emission reductions. The estimated increase in soil organic matter by use of organic fertilizer constitutes only $2-5 \%$ of the total benefits of the considered systems, but enough to offset $75-81 \%$ of the estimated nitrous oxide emissions from the use of organic fertilizer.

\subsection{Uncertainty analysis}

Due to the scarcity of accurate context-specific data (i.e. about emissions from transportation, composting, AD or biochar production) and the many unknowns of soil carbon dynamics (both for organic carbon and for biochar sequestration) a lot of the values used in the inventory have a high level of uncertainty. Uncertainty ranges were derived from a literature review of similar studies for the most uncertain values, as detailed in Table 1. Fig. 3 shows the magnitude of these uncertainties (the bars) and, for comparison, the total emissions of the COMPOST and BIOGAS scenarios (horizontal lines).

The most important uncertainties in absolute terms are how much carbon is sequestered as biochar and how much $\mathrm{CH}_{4}$ is formed in the landfill. The former depends on soil properties, biochar properties and climate, and it can be best estimated by long term field trials. The latter depends mainly on the depth of the landfill (UNFCCC, 2010), and it is difficult to estimate in developing countries (Friedrich and Trois, 2011). How much GHG are formed during the composting process is also a very large uncertainty for all scenarios. Alone it amounts to $67 \%$ of the total emissions of COMPOST and $94 \%$ of the total emissions of BIOGAS. This high value is due to the fact that $\mathrm{N}_{2} \mathrm{O}$, which is a very powerful GHG, with a Global Warming Potential of 310 , can form in compost heaps. The actual amount generated depends on how the heaps are managed and on feedstock properties and is hard to estimate without direct measurements. Other uncertain values are also significant, but less than the ones above.

The biggest uncertainties, biochar sequestration, formation of $\mathrm{CH}_{4}$ in compost heaps and the landfill and $\mathrm{N}_{2} \mathrm{O}$ formation in compost heaps are hard to reduce, because their values depend on microbiological processes which are hard to model and predict. The results show however also that the total uncertainty can be significantly reduced by more accurate technical data about biochar and biogas yields.

\section{Economic assessment}

\subsection{Data used}

An economic model, with initial investment, operating costs and revenues associated with the start-up and operation of the considered systems was built and used to evaluate their economic 
Table 2

Life cycle impact assessment results.

\begin{tabular}{|c|c|c|c|c|c|}
\hline \multirow[t]{2}{*}{ Life cycle stage } & \multirow[t]{2}{*}{ Process } & \multicolumn{4}{|c|}{ GHG emissions ( $\mathrm{t} \mathrm{CO}_{2}$ eq) } \\
\hline & & Baseline & Compost & Biogas & Biochar \\
\hline Capital goods & & 2.71 & 65.55 & 73.4 & 128.24 \\
\hline \multirow[t]{4}{*}{ Waste transport } & OMSW to plant or landfill & 8.02 & 7.54 & 7.54 & 7.54 \\
\hline & Shea waste to plant & & 2.29 & 2.29 & 2.29 \\
\hline & Poultry manure to plant & & 142.58 & 142.58 & 142.58 \\
\hline & Rice husks to plant & & & & 15.37 \\
\hline \multirow[t]{5}{*}{ Waste processing/fertilizer production } & Landfilling organic & 956.27 & 0 & 0 & 0 \\
\hline & Composting & & 265.5 & 265.5 & 265.5 \\
\hline & Anaerobic digestion & & & 31.5 & \\
\hline & Rice husks burning & 0 & 0 & 0 & \\
\hline & Rice husks pyrolysis & & & & 0 \\
\hline \multicolumn{2}{|l|}{ NPK fertilizer production } & 60.75 & & & \\
\hline \multirow[t]{2}{*}{ Fertilizer transport } & Chemical fertilizer transport & 12.46 & & & \\
\hline & Organic fertilizer/biochar transport & & 25.93 & 25.93 & 32.15 \\
\hline \multirow[t]{3}{*}{ Fertilizer use } & $\mathrm{N}_{2} \mathrm{O}$ emissions from soil & 39.42 & 41.65 & 41.65 & 37.98 \\
\hline & Soil organic carbon sequestration & & -31.20 & -31.20 & -31.20 \\
\hline & Biochar sequestration & & & & -1108.8 \\
\hline \multirow[t]{2}{*}{ Energy production } & Diesel generator & 271.53 & 271.53 & & 271.53 \\
\hline & Biogas generator & & & 0 & \\
\hline Other & Flights & & 6.37 & 6.37 & 6.37 \\
\hline \multirow{3}{*}{\multicolumn{2}{|c|}{$\begin{array}{l}\text { Total GHG emissions } \\
\text { Difference compared to BASELINE } \\
\text { (\% Difference compared to BASELINE) }\end{array}$}} & 1351.16 & 797.74 & 565.55 & -230.45 \\
\hline & & & -553.42 & -785.61 & -1581.61 \\
\hline & & & $(-41.0 \%)$ & $(-58.1 \%)$ & $(-117.1 \%)$ \\
\hline
\end{tabular}

feasibility as well as the influence upon it of potential revenues from the sale of carbon credit.

Several factors influence negatively the capacity to predict future cash flows and evaluate the performance of the investment for a long time span.

Mainly, compost, biochar and renewable electricity are not products that are widely traded in Northern Ghana as of now, so the market price at which they can be sold is not certain. Because of this high uncertainty a single period ratio was preferred, without time series of costs and revenues and with no need for discounting. The ratio used is the Return on Investment (ROI), defined as ROI = Profit/(Operation Costs + Annuity). The annuity (annual repayment of the initial investment) was calculated over a period of 10 years at an interest rate of $10 \%$. Economic feasibility was defined as ROI $>5 \%$.

Initial investment costs include the cost of land, equipment, buildings, machines, reactors and vehicles. Costs for the composting plant and the digesters are based on the figures provided by DeCo and by Burri and Martius (2011). Capital costs for biochar systems in the literature range from 11 to $63 \mathrm{EUR} / \mathrm{t}$ of annual feedstock processing capacity (Roberts et al., 2010; Islam and Ani, 2000; Meyer et al., 2011; Shackley et al., 2012b), although figures from the private sector go up to 500 (Fournier, 2009). Here a value of $25 \mathrm{EUR} / \mathrm{t}$ feedstock was considered, equivalent to $60,000 \mathrm{EUR}$ total equipment cost, which is the cost of a common rice husks gasification system in Cambodia according to Shackley et al. (2012b), plus estimated construction costs of $10,000 €$. Operating costs include staff, purchase and transport of raw materials, utilities (electricity and water) and fuel costs. Taxes are not included and $5 \%$ is added for maintenance and overhead expenses. In COMPOST the only revenues are from the sale of organic fertilizer, BIOGAS has additionally the sale of electricity, BIOCHAR the sale of biochar. Fertilizer was assumed to be sold at $40 \mathrm{EUR} /$ ton, electricity at $0.04 \mathrm{EUR} / \mathrm{kW} \mathrm{h}$ and biochar at $15 \mathrm{EUR} / \mathrm{ton}$, which is the price of the residue of traditional charcoal production, a mix of charcoal powder and dirt, which has been used for biochar field trials in the region (Abokobi Society Switzerland, unpublished results). Carbon credits, or Voluntary Emission Reductions (VER, $1 \mathrm{VER}=1 \mathrm{tCO}_{2}$ eq) were considered to be generated from landfill

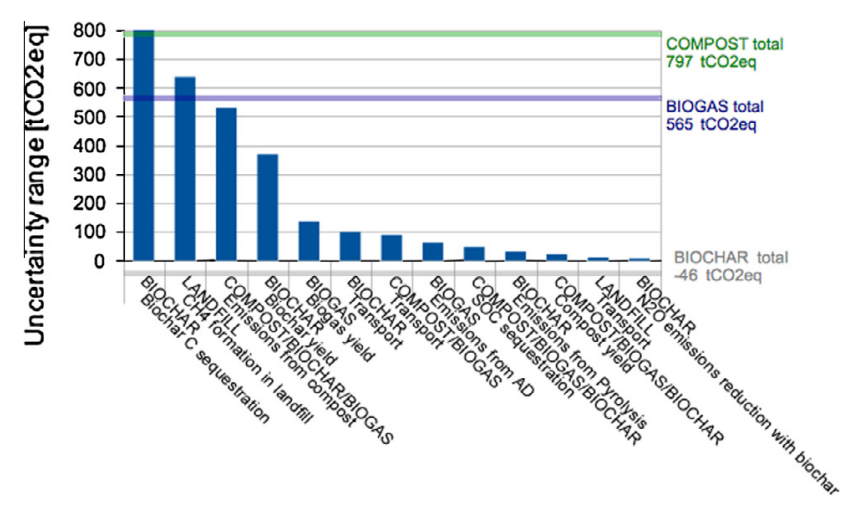

Fig. 3. Uncertainty analysis of LCA results. Uncertainty of selected LCA values in comparison with total carbon footprint of scenarios.

avoidance for 0.14 tons of carbon per ton of MSW, from renewable energy production for 0.79 tons of carbon per $\mathrm{MW} h$, from biochar sequestration for 1.65 tons of carbon per ton of biochar applied. The former two values were calculated using the relevant CDM methodologies (UNFCCC, 2010, 2011), the latter is derived from the GHG footprint model under the assumption that all carbon sequestered could be translated into carbon credits. The considered price of carbon is $7 \mathrm{EUR} / \mathrm{t} \mathrm{CO}_{2} \mathrm{eq}$, a price that at the time of writing is realistic on voluntary markets, but very optimistic on compliance markets. Finally, accessing carbon revenues requires official accreditation and the filing of annual monitoring reports. These translate into substantial costs that were not included here, assuming that they are born by an external partner, a carbon consultant/broker, which subsequently purchases the credits.

\subsection{Results}

As shown in Table 3, all alternatives have a negative ROI as the revenues are not sufficient to cover the costs. The difference between the results with and without carbon credits (VER) is not very significant, and the loss is between $15 \%$ and $25 \%$ of running costs in all scenarios. 
The integration of a biogas system cannot improve the viability of a composting system, as shown by the fact that BIOGAS has a lower ROI than COMPOST. Integrating a biochar system without the additional revenues from the sale of carbon credits would not be justified from an economic point of view, since BIOCHAR has a higher ROI than composting only with access to carbon markets. Many uncertain parameters have been used to evaluate the feasibility of the project, from the prices paid for compost, biochar and electricity to the price of carbon credits to the cost paid/fee charged for organic waste collection. In the following section the sensitivity of the results to carbon price is discussed. In Sections 5.2 and 5.3 the importance of organic waste cost and biochar price are also discussed.

\subsection{Sensitivity to carbon price}

The carbon price that, ceteris paribus, would be required to achieve a satisfactory ROI was also calculated. Fig. 4 shows the sensitivity of ROI to carbon price.

The slope of the curves depends on the amount of carbon credits generated, so BIOCHAR has the steepest slope, followed by BIOGAS, while COMPOST's profitability is the one that grows the least with increasing carbon prices. Composting alone, in fact, generates 1 VER every 7.2 tons of fertilizer produced, while in BIOGAS 1 VER is generated every 4.5 tons of fertilizer. In biochar production carbon revenues would be much more conspicuous, with 1 VER generated every 0.6 tons of biochar produced.

COMPOST becomes viable, with a ROI above $5 \%$, at a carbon price of 84 EUR/VER. BIOGAS does not perform significantly better and becomes feasible with a carbon price of 78 EUR/VER. BIOCHAR, which is the scenario with the worst economic performance without access to carbon markets, is also the one that generates the most VER, combining the emission reductions of composting and biochar sequestration. It would only need a carbon price of 31 EUR/VER to reach a ROI of $5 \%$.

\section{Discussion}

\subsection{GHG benefits of composting and anaerobic digestion from a life cycle perspective}

Both composting and AD have been found to have a substantial potential for reducing GHG emissions of organic waste management in Tamale, by respectively $41 \%$ and $58 \%$ compared to business as usual (open landfill).

To compare the findings with similar studies, values per unit of waste input are calculated. Here 1 part of MSW was considered to be mixed together for composting with 1 part of other local biomass (shea butter production waste and dry neem leaves) and 1 part of poultry manure imported from the South of Ghana. Since different feedstocks have different business-as-usual scenarios (landfill for MSW, aerobic decomposition for other local biomass, agricultural use for poultry manure) they should also be allocated different GHG benefits. Landfill avoidance is fully allocated to MSW, while fertilizer substitution is divided between MSW and other local biomass, on the basis of their Nitrogen content. The GHG mitigation benefit of composting for MSW compared to business as usual is therefore $0.51 \mathrm{tCO}_{2} \mathrm{eq} / \mathrm{t}$ waste $\left(0.14 \mathrm{t} \mathrm{CO}_{2} \mathrm{eq} /\right.$ t waste for other biomass), a substantial reduction, but somewhat lower than the estimations by Aye and Widjaya (2006) in Indonesia of $0.66 \mathrm{t} \mathrm{CO}_{2} / \mathrm{t}$ waste. The difference is explained primarily by the low nutrient density of Tamale's MSW compost, which requires enrichment with poultry manure imported from a distance of $370 \mathrm{~km}$ and reduces the benefits from NPK fertilizer substitution. Barton et al. (2008) found even higher abatement potential of
0.7-1.2 $\mathrm{t} \mathrm{CO}_{2}$ eq/t MSW, but this results do not include any GHG emissions for transport and capital goods. In the results presented in this paper emissions from the composting process itself are quite low, $0.09 \mathrm{t} \mathrm{CO}_{2} \mathrm{eq} / \mathrm{t}$ waste as opposed to values in literature of $0.18-0.93 \mathrm{t} \mathrm{CO}_{2} \mathrm{eq} / \mathrm{t}$ waste (Aye and Widjaya, 2006; Friedrich and Trois, 2013; Lundie and Peters, 2005), because all processes are performed by hand. They remain however an important uncertainty (see Fig. 3 in Section 3.3).

Extracting energy from MSW with AD would increase GHG mitigation potential by an extra $0.17 \mathrm{t} \mathrm{CO}_{2} \mathrm{eq} / \mathrm{t} \mathrm{MSW}$ compared to direct composting. Three other studies compared AD and composting in developing countries and found this value to be $0.09 \mathrm{t} \mathrm{CO}_{2}$ eq/t MSW (Aye and Widjaya, 2006), $0.21 \mathrm{t} \mathrm{CO}_{2}$ eq/t MSW (Barton et al., 2008) and 0.23 t CO $_{2}$ eq/t MSW (Friedrich and Trois, 2011). Specifically in the case of Ghana, in gray literature Wikner (2009) performed an LCA of AD of MSW in another Ghanaian city, and found that the benefit across the life cycle amount to $0.99 \mathrm{tCO}_{2}$ eq/t MSW compared to uncontrolled landfill. The value is higher than that found by this study of $0.67 \mathrm{t} \mathrm{CO}_{2} \mathrm{eq} / \mathrm{t} \mathrm{MSW}$, and the difference is explained mainly by emissions from transport, as well as capital goods. Finally, Nzila et al. (2012) estimated the GHG balance of farm-scale AD in Kenya, excluding baseline methane formation but including energy (kerosene) and fertilizer substitution, to be about neutral. The difference with the value found in this study (net emissions $0.06 \mathrm{t} \mathrm{CO}_{2} \mathrm{e} / \mathrm{t}$ waste) is also connected mainly to transport emissions, which are absent in the model by Nzila et al. (2012).

\subsection{Economic viability of using organic waste for soil restoration, nutrient cycling and energy}

Altogether composting was found to be not viable without external subsidies in Northern Ghana. Literature about composting in developing countries uses very different estimates for both production costs and compost prices, but generally agrees that subsidies are needed for it to be economically feasible (Danso et al., 2006; Cofie et al., 2009; Couth and Trois, 2012b). Nonetheless the required carbon price for viability of compost in Tamale was found to be $84 € /$ VER (117 US\$ considering the 2011 average exchange rate of $1.4 \$ /$ EUR), while Couth and Trois (2012b) state that $16 \$$ would be sufficient for viability. Furthermore, in two out of two detailed economic assessments of composting case studies in developing countries found in literature, composting was considered viable without subsidies, both in Bangladesh (Zurbrugg et al., 2002) and Indonesia (Aye and Widjaya, 2006). The difference can be explained by the cost of feedstock, which amounts to as much as $60 \%$ of operation costs in the considered Ghanaian scenario (12.50€/t MSW, $20 € / \mathrm{t}$ poultry manure and neem leaves, $10 € / \mathrm{t}$ shea waste, weighted average $15.8 € / \mathrm{t}$ waste), while they are null in the Jakharta case (Aye and Widjaya, 2006) and constitute a revenue, in fact $37 \%$ of total revenues, in the case of Dhaka (Zurbrugg et al., 2002). These results point to the fact that also in the North of Ghana composting could be economically self-sustaining if it would combine fertilizer sales with the provision of a waste management service.

The analysis has shown that digesting anaerobically MSW before composting is also not a viable option without subsidies. Access to carbon revenues make the combined $\mathrm{AD}$ and composting operations viable at a carbon price of $78 € /$ VER (109\$). Other studies assessing different $\mathrm{AD}$ systems in developing countries have however found it to be quite viable. Salum and Hodes (2009) find on-site AD of waste for the sisal agro-industry to be viable in Tanzania with a carbon price of $15 \$$ and Nzila et al. (2012) find AD to be very profitable at household level in Kenya even without carbon revenues. Aye and Widjaya (2006) find it to be barely feasible in Jakharta, but worse than composting, due to very high initial costs, 
Table 3

Economic assessment.

\begin{tabular}{|c|c|c|c|c|}
\hline & & Compost (EUR) & Biogas (EUR) & Biochar (EUR) \\
\hline Initial investment & $\begin{array}{l}\text { Composting plants } \\
\text { Digesters } \\
\text { Generators } \\
\text { Vehicles } \\
\text { Biochar reactor } \\
\text { Total investment }\end{array}$ & $\begin{array}{l}68,100 \\
16,000 \\
\mathbf{8 4 , 1 0 0}\end{array}$ & $\begin{array}{l}69,540 \\
42,400 \\
20,000 \\
16,000 \\
147,940\end{array}$ & $\begin{array}{l}78,100 \\
\\
16,000 \\
70,000 \\
\mathbf{1 6 4 , 1 0 0}\end{array}$ \\
\hline Operation costs & $\begin{array}{l}\text { Staff } \\
\text { Organic waste } \\
\text { Fuel } \\
\text { Utilities } \\
\text { Overhead and maintenance } \\
\text { Total operation costs } \\
\text { Annuity (capital cost) }\end{array}$ & $\begin{array}{l}49,900 \\
71,250 \\
5101 \\
400 \\
6333 \\
\mathbf{1 3 2 , 9 8 3} \\
\mathbf{1 3 , 6 8 7}\end{array}$ & $\begin{array}{l}64,360 \\
71,250 \\
5101 \\
1140 \\
7093 \\
\mathbf{1 4 8 , 9 4 3} \\
\mathbf{2 4 , 0 7 7}\end{array}$ & $\begin{array}{l}52,264 \\
71,250 \\
11,722 \\
400 \\
6782 \\
\mathbf{1 3 0 , 8 0 0} \\
\mathbf{2 6 , 7 0 7}\end{array}$ \\
\hline Revenues & $\begin{array}{l}\text { Compost } \\
\text { Electricity } \\
\text { Biochar } \\
\text { Total revenues }\end{array}$ & $\begin{array}{r}120,000 \\
\mathbf{1 2 0 , 0 0 0}\end{array}$ & $\begin{array}{l}120,000 \\
12,068 \\
\\
\mathbf{1 3 2 , 0 6 8}\end{array}$ & $\begin{array}{l}120,000 \\
10,800 \\
\mathbf{1 3 0 , 8 0 0}\end{array}$ \\
\hline Additional VER revenues & $\begin{array}{l}\text { VER avoided landfill } \\
\text { VER renewable energy } \\
\text { VER biochar } \\
\text { Total VER revenues }\end{array}$ & $\begin{array}{l}2835 \\
\mathbf{2 8 3 5}\end{array}$ & $\begin{array}{l}2835 \\
1666 \\
\mathbf{4 5 0 1}\end{array}$ & $\begin{array}{l}2835 \\
7762 \\
10,597\end{array}$ \\
\hline Profit & $\begin{array}{l}\text { Without VER revenues } \\
\text { with VER revenues }\end{array}$ & $\begin{array}{l}-26,670 \\
-23,835\end{array}$ & $\begin{array}{l}-40,952 \\
-36,451\end{array}$ & $\begin{array}{l}-38,324 \\
-27,727\end{array}$ \\
\hline ROI & $\begin{array}{l}\text { Without VER } \\
\text { With VER }\end{array}$ & $\begin{array}{l}-18.18 \% \\
-16.25 \%\end{array}$ & $\begin{array}{l}-23.67 \% \\
-21.07 \%\end{array}$ & $\begin{array}{l}-22.66 \% \\
-16.39 \%\end{array}$ \\
\hline
\end{tabular}

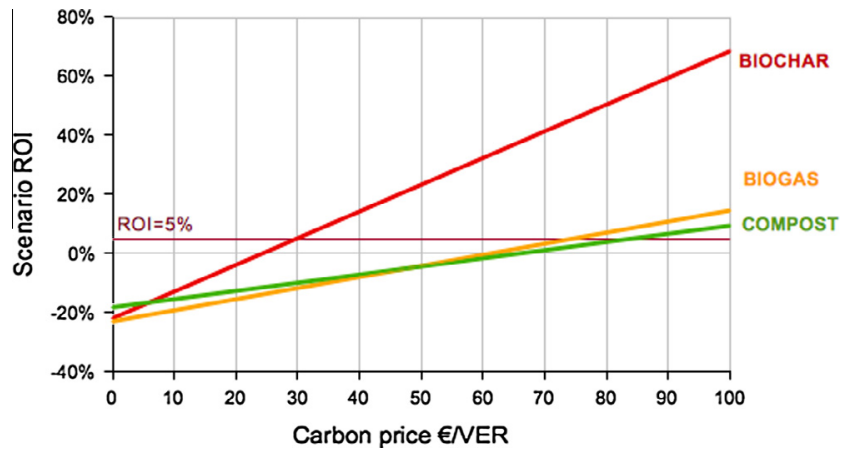

Fig. 4. ROI sensitivity to carbon price. Variation of ROI (Return on Investment) of the considered systems with varying price of carbon (VER: Voluntary Emission Reductions $\left.=1 \mathrm{t} \mathrm{CO}_{2} \mathrm{eq}\right)$. $\mathrm{ROI}=5 \%$ is the chosen value for economic feasibility.

i.e. for land and machinery (156\$/t waste as opposed to $64 \$ / \mathrm{t}$ waste in Tamale). As for composting, the bad economic performance of $\mathrm{AD}$ in Tamale is also explained mainly by the high cost of waste. An economic opportunity could lie in digesting anaerobically not only MSW but also the shea waste that is composted with it, following the findings of Ofosu and Aklaku (2010). This would generate higher revenues from sales of electricity and VER, at similar operational costs. Finally it could be the case that digesting MSW first would increase the nutrient density of the resulting compost, thus reducing or eliminating the need for enrichment, increasing the fertilizer quality, and reducing transportation costs for the end users (since less compost per hectare would be needed). Future research should focus therefore on what types of waste can be digested, and what is the quality of the digestion residue.

\subsection{The economic and environmental potential of biochar}

To compare the GHG mitigation benefit of the considered biochar system with similar studies in the literature, reductions are averaged per unit of rice husks processed. The resulting net benefit is $0.43 \mathrm{t} \mathrm{CO}_{2} \mathrm{eq} / \mathrm{t}$ waste, and, since life cycle emissions are small (less than $10 \%$ of the sequestration), this value is strongly related to the assumptions about how much of the $C$ in the biomass is actually sequestered in soil (here $0.46 \mathrm{t} \mathrm{CO}_{2} \mathrm{eq} / \mathrm{t}$ waste). Other LCAs of biochar focusing on developing countries found similar results. Two similar case studies presented in Scholz et al. (2014), from Vietnam and Senegal, also come to the conclusion that the climate mitigation potential of biochar is $0.4 / 0.5 \mathrm{t} \mathrm{CO}_{2}$ eq/t waste. A Zambian case study (Sparrevik et al., 2013) assesses the benefits of using biochar produced in a small scale low tech retort kiln from agricultural waste in a conservation agriculture system. The final results are very similar, as the net reduction is calculated to be $0.44-0.46 \mathrm{tCO}_{2} \mathrm{eq} / \mathrm{t}$ waste, depending on the actual yield increases achieved. However their model highlights higher carbon sequestration $\left(0.78 \mathrm{t} \mathrm{CO}_{2} \mathrm{eq} / \mathrm{t}\right.$ waste $)$ balanced by higher GHG emissions along the life cycle, especially fugitive methane emissions during pyrolysis, compared to our research. Another case study by the same authors (Sparrevik et al., 2014) analyzing biochar production from cocoa waste in cookstoves in Indonesia quantified the GHG benefits at $0.33 \mathrm{t} \mathrm{CO}_{2} \mathrm{eq} / \mathrm{t}$ waste. Shackley et al. (2012b) look at rice husks biochar produced in small-scale gasifiers in Cambodia. Their study is not a full LCA but rather a GHG balance of the gasification system, and estimates its net benefits at $0.82-0.84 \mathrm{t} \mathrm{CO}_{2} \mathrm{eq} / \mathrm{t}$ waste including energy production. Excluding energy generation the net GHG mitigation is of 0.38 $0.40 \mathrm{t} \mathrm{CO}_{2} \mathrm{eq} / \mathrm{t}$ waste. The same study also highlights the fact that the benefits go up to $4.4 \mathrm{t} \mathrm{CO}_{2} \mathrm{eq} / \mathrm{t}$ waste if the baseline is anaerobic decomposition of the husks in rice paddies. Focusing on U.S. case studies with coupled energy and biochar production, Field et al. (2013) and Roberts et al. (2010) found values in the range of $0.55-0.89 \mathrm{t} \mathrm{CO}_{2} \mathrm{eq} / \mathrm{t}$ waste, depending on technology and feedstock choice. Carbon sequestration is assumed to account for, respectively, 0.76 and $0.59 \mathrm{t} \mathrm{CO}_{2} \mathrm{eq} / \mathrm{t}$ waste), and the former found that in most cases using biochar for energy production instead of agriculture creates better GHG benefits. Finally Ibarrola et al. (2012) analyzed the GHG footprint of various scenarios of biochar production with different technologies and types of organic waste 
in the U.K. finding net sequestration ranging between 0.07 and $1.25 \mathrm{t} \mathrm{CO}_{2} \mathrm{eq} / \mathrm{t}$ waste, but none of the scenarios is really comparable to the one studied in this paper.

The fact that the results presented in this study are in line with those found by others shows that biochar systems have indeed potential to mitigate GHG emissions. How much this reduction will amount to depends on the baseline use for the biomass (i.e. energy recovery, aerobic decomposition or anaerobic decomposition), whether energy is also produced with pyrolysis, and how much carbon is assumed to be sequestered per unit of biomass waste. The latter cannot be determined with certainty with current technology, and depends on char yield and the share of recalcitrant carbon, hydrogen and oxygen in the biochar. In the case of Tamale, it was found that life cycle emissions (infrastructure and transportation) are very low, also including uncertainty ranges, so the benefit of carbon sequestration is maximized. Two cases (Sparrevik et al., 2013; Field et al., 2013) stress the importance of controlling fugitive emissions from pyrolysis that were not included in this study. Energy production together with biochar production would further increase the GHG mitigation potential, but using rice husks to produce only energy could even prove to be better from this point of view, and a separate assessment is needed, also including a quantification of agricultural benefits from using rice husks biochar and a technology-specific assessment of fugitive GHG emissions from pyrolysis.

The economic assessment of biochar production in Tamale found it to be not viable, alongside composting, without subsidies. One of the goals of the analysis was to determine whether coproducing biochar with compost could improve its business case by creating economies of scale in terms of marketing and logistics, although a firm answer cannot be given because not many studies focusing on developing countries can be easily used for comparison. The economic analyses of biochar in developing regions found (Pratt and Moran, 2010; Shackley et al., 2012b; Sparrevik et al., 2014; Scholz et al., 2014) are based on different premises. Pratt and Moran (2010) state that biochar is viable in Africa, considering carbon price as low as $6 \$(4.3 €)$ but do not provide the list of assumptions used. Shackley et al. (2012b) focus on the observation of a viable gasification energy system which has biochar as a byproduct. Sparrevik et al. (2014) look at decentralized biochar production in Indonesia from the perspective of a household looking at a variety of economic and non-economic costs and benefits. Scholz et al. (2014) present two studies taking the same perspective in Kenya and Vietnam, but include also a case study from Senegal where biochar is centrally produced from rice husks, in a scenario similar to that presented in this paper. Their results suggest that biochar production is profitable for farmers that use it but not for the producer, who incurs a loss of $30 \$(21 €) / t$ waste. It can be calculated that subsidies of $73 \$(52 €) / \mathrm{tCO}_{2} \mathrm{eq}$, much higher than those here estimated of $30 € / \mathrm{t} \mathrm{CO}$ eq, would be needed to cover this gap, even though in the study biochar is sold at the higher price of $200 \$(143 €) / t$. The main reason for the much lower profitability in Scholz et al. (2014) is capital costs, more than 4 times higher than those assumed here per unit of waste treated. Other economic assessments of biochar systems, all focusing on the U.S., find that carbon revenues are needed to ensure viability, and that the prices of carbon and biochar, both highly uncertain factors, are the main determinants for assessing system profitability (Galinato et al., 2011; Field et al., 2013; Roberts et al., 2010). In comparable case studies (pyrolysis of agricultural waste) required carbon prices (for $1 \mathrm{t} \mathrm{CO}_{2}$ eq) are respectively 1-31\$, (with a biochar price between 12 and $100 \$ /$ t char, Galinato et al., 2011), $50-150 \$$ (depending on technology used and energy recovery levels, Field et al., 2013) and 2-40 \$ (depending on feedstock choice, its location and baseline use, with biochar price of 40-70 \$/t char, Roberts et al., 2010). In Tamale, Ghana, biochar coproduction was found to improve the economic performance of composting with a carbon price of $7 €(9.8 \$) / V E R$ and biochar price of $15 €(20 \$) /$ $\mathrm{t}$ char, although still operating at a loss unless the former would rise to $10 €(14 \$) /$ VER or the latter to $20 €(28 \$) / t$ char (excluding the viability of the composting system). These results point out that biochar could indeed be more viable in this context, when coproduced with compost in an area where agriculture could really benefit from it. However these results only hold if biochar is accepted as a methodology for carbon credit generation by the UNFCCC and it is proved that farmers are willing to pay such a price for it, or in other words that its agricultural value would be higher than its price. At the considered price of $15 €(20 \$) / t$ char, based on observation of the market price of charcoal production byproduct, a carbon price of $30 €(42 \$) / V E R$ would make the combined composting-biochar system economically viable. Such a carbon price is not unrealistic on voluntary markets.

\section{Conclusions}

This research has looked at quantifying the potential climate benefits of organic waste recycling through composting, $A D$ and biochar production in Tamale, and at how carbon markets can facilitate the realization of this potential.

Three alternatives based on low-tech, small scale variants of composting, $\mathrm{AD}$ and pyrolysis were analyzed and compared from the point of view of GHG emission reduction potential, costs, revenues, and potential for carbon credit generation.

It was found that these technologies can give a significant contribution to climate change mitigation through landfill avoidance, energy production, sequestration of carbon in soils and avoided use of NPK fertilizer. However they are not economically viable without receiving external subsidies. Carbon markets can help the realization of these organic waste management systems, although not at the current carbon price levels, which are too low. With higher carbon prices, the contribution of carbon markets to the economic feasibility of all the three technologies could become substantial. Biochar sequestration is the activity that would benefit the most from access to carbon markets, although conditionally to the approval of biochar sequestration as a carbon credit generating mechanism. Extracting biogas from the waste before composting would increase carbon revenues (compared to composting alone) by about $60 \%$. The minimum carbon prices that would allow to reach an acceptable rate of return, would then be lowest for biochar production with composting (31 EUR/VER), highest for composting alone (84 EUR/VER) and in between for anaerobic digestion (78 EUR/VER).

\section{Acknowledgements}

The authors would like to thank the staff at DeCo! - Sustainable farming, Dr. Fosu at the Savannah Agricultural Research Institute in Tamale and Abokobi Society Switzerland for the collaboration during the research.

\section{References}

Abokobi Society Switzerland, 2013, Biochar <http://www.abokobi.ch/47/Projekte/ Biochar.html> (13.01.14).

American Carbon Registry (ACR), 2013. Methodology for Biochar Projects. American Carbon Registry <http://americancarbonregistry.org/carbon-accounting/ methodology-for-biochar-projects> (June 2014).

Alfsen, K.H. et al., 1997. Soil degradation and economic development in ghana. Environ. Dev. Econ. 2 (02), 119-143.

Al-Hassan, R., Poulton, C., 2009. Agriculture and Social Protection in Ghana, Future Agricultures Working paper 009.

American Carbon Registry, 2013. Methodology for Biochar Projects <http:// americancarbonregistry.org/carbon-accounting/methodology-for-biocharprojects> (January 2014). 
Arthur, R., Baidoo, M.F., Antwi, E., 2011. Biogas as a potential renewable energy source: a Ghanaian case study. Renew. Energy 36 (5), 1510-1516.

Australian Department of Environment, 2013. Methodologies <http:// www.climatechange.gov.au/reducing-carbon/carbon-farming-initiative/ methodologies> [February 2014].

Aye, L., Widjaya, E.R., 2006. Environmental and economic analyses of waste disposal options for traditional markets in Indonesia. Waste Manage. 26 (10), 11801191.

Barton, J.R., Issaias, I., Stentiford, E.I., 2008. Carbon - making the right choice for waste management in developing countries. Waste Manage. 28 (4), 690-698.

Bensah, E.C., Brew-Hammond, A., 2010. Biogas technology dissemination in Ghana: history, current status, future prospects, and policy significance. Int. J. Energy Environ. 1, 277-294.

Bensah, E.C., Mensah, M., Antwi, E., 2011. Status and prospects for household biogas plants in Ghana-lessons, barriers, potential, and way forward. Int. J. Energy Environ. 2, 887-898.

Biala, J., 2011. The Benefits of Using Compost for Mitigating Climate Change. Technical Report, Department of Environment, Climate Change and Water NSW, Sydney.

Blench, R., 2007. Working Paper: Agricultural Production and the Potential for Commodity Chain Expansion in the Three Northern Regions of Ghana in 2006. Cambridge <http://www.rogerblench.info/Development/Ghana/FAO/ Blench\%20Working\%20Paper\%20Ghana\%202006\%20revised.pdf>.

Boldrin, A. et al., 2009. Composting and compost utilization: accounting of greenhouse gases and global warming contributions. Waste Manage. Res. 27 (8), 800-812.

Boyd, A., 2012. Informing international UNFCCC technology mechanisms from the ground up: using biogas technology in South Africa as a case study to evaluate the usefulness of potential elements of an international technology agreement in the UNFCCC negotiations process. Energy Policy 51, 301-311.

Braimah, A.S., 2011. West Africa: ECOWAS as the Change Agent for West Africa. allAfrica.com, 1 September 2011 <http://allafrica.com/stories/ 201109021039.html> (February 2012).

Brown, S., Kruger, C., Subler, S., 2008. Greenhouse gas balance for composting operations. J. Environ. Qual 37, 1396-1410.

Burri, M., Martius, G., 2011. Biogas from Solid Waste. Conception and Construction of a Dry Fermentation Pilot Plant for Developing Countries. Masters thesis. ETH Zurich, Zurich

Butler, J., Hooper, P., 2010. Down to Earth: an illustration of life cycle inventory good practice with reference to the production of soil conditioning compost. Resour. Conserv. Recy. 55 (2), 135-147.

Cofie, O.O. et al., 2009. Resource recovery from urban waste: options and challenges for community-based composting in sub-Saharan Africa. Desalination 248 (13), 256-261.

Couth, Trois, 2010a. Waste management activities and carbon emissions in Africa. Waste Manage. 31 (11), 131-137.

Couth, R., Trois, C., 2010b. Carbon emissions reduction strategies in Africa from improved waste management: a review. Waste Manage. 30 (11), 2336-2346.

Couth, R., Trois, C., 2012a. Sustainable waste management in Africa through CDM projects. Waste Manage. 32 (11), 2115-2125.

Couth, R., Trois, C., 2012b. Cost effective waste management through composting in Africa. Waste Manage. 32 (12), 2518-2525.

Danso, G., Drechsel, P., Fialor, S., Giordano, M., 2006. Estimating the demand for municipal waste compost via farmers' willingness-to-pay in Ghana. Waste Manage. 26 (12), 1400-1409.

De Groot, M., 2010. Update of Emission Factors for $\mathrm{N}_{2} \mathrm{O}$ and $\mathrm{CH}_{4}$ for Composting, Anaerobic Digestion and Waste Incineration. Technical Report version 3, DHV B.V., Amersfoort, The Netherlands.

De Klein, C., Novoa, R.S., Ogle, S., Smith, K.A., Rochette, P., Wirth, T.C., McConkey, B.G., Mosier, A., Rypdal, K., 2006, Chapter 11: $\mathrm{N}_{2} \mathrm{O}$ emissions from managed soils, and $\mathrm{CO}_{2}$ emissions from lime and urea application. In: Guidelines for National Greenhouse Gas Inventories, Agriculture, Forestry and Other Land Use, IPCC, vol. 4.

Derbile, E.K., 2010. Local Knowledge and Livelihood Sustainability under Environmental Change in Northern Ghana. Doctoral dissertation. University of Bonn, Bonn.

Drechsel, P., Kunze, D. (Eds.), 2001. Waste Composting for Urban and Peri-urban Agriculture: Closing the Rural-urban Nutrient Cycle in Sub-Saharan Africa, CABI.

Drechsel, P., Cofie, O., Fink, M., Danso, G., Zakari, F., Vasquez, R., 2004. Closing the Rural-Urban Nutrient Cycle. Options for Municipal Waste Composting in Ghana. Final Scientific Report on IDRC Project 100376, IWMI-West Africa, Accra.

Duku, M.H., Gu, S., Hagan, E.B., 2011. Biochar production potential in Ghana - a review. Renew. Sust. Energy Rev. 15 (1), 3539-3551.

Ecoinvent, 2010. Life Cycle Inventory Data Version 2.01. Dbendorf: Swiss Centre for Life Cycle Inventories.

Edelmann, W., Schleiss, K., Joss, A., 2000. Ecological, energetic and economic comparison of anaerobic digestion with different competing technologies to treat biogenic wastes. Water Sci. Technol.: J. Int. Assoc. Water Pollut. Res. 41 (3), $263-273$.

Field, J.L., Keske, C.M.H., Birch, G.L., DeFoort, M.W., Cotrufo, M.F., 2013. Distributed biochar and bioenergy coproduction: a regionally specific case study of environmental benefits and economic impacts. GCB Bioenergy 5, 177-191.

Fournier, J., 2009. Low temperature pyrolysis for biochar systems. In: Presentation held at the 2009 Harvesting Clean Energy Conference, January 2009, Billings, MT <http://harvestcleanenergy.org/2010-conference-resources/2009- harvesting-clean-energy-conference/2009-conference-presentations/fournierpdf $>$ (February 2012).

Friedrich, E., Trois, C., 2011. Quantification of greenhouse gas emissions from waste management processes for municipalities - a comparative review focusing on Africa. Waste Manage. 31 (7), 1585-1596.

Friedrich, E., Trois, C., 2013. GHG emission factors developed for the recycling and composting of municipal waste in South African municipalities. Waste Manage. 33 (11), 2520-2531.

Galinato, S.P., Yoder, J.K., Granatstein, D., 2011. The economic value of biochar in crop production and carbon sequestration. Energy Policy 39, 6344-6350.

Gaunt, J.L., Lehmann, J., 2008. Energy balance and emissions associated with biochar sequestration and pyrolysis bioenergy production. Environ. Sci. Technol. 42, 4152-4158.

Ghanaweb, 2014. New Organic Compost Improves Yields|Business News 8 February $2014<$ <ttp://www.ghanaweb.com/GhanaHomePage/NewsArchive artikel.php?ID=300074> (June 2014).

Guinée, J.B., 2002. Handbook on Life Cycle Assessment: Operational Guide to the ISO Standards. Kluwer Academic Publishers, Dordrecht, The Netherlands.

Haefele, S.M., Konboon, Y., Wongboon, W., Amarante, S., Maarifat, A.A., Pfeiffer, E.M., Knoblauch, C., 2011. Effects and fate of biochar from rice residues in rice-based systems. Field Crops Res. 121 (3), 430-440.

Hine, J., Sinaga, H.P., 2001. ARFCOM, Speed Profiles and Fuel Consumption: Results from a Congested Road in Java. Technical report, International Division Transport Research Labo-ratory, Crowthorne, UK <http://www.transportlinks.org/transportlinks/filearea/publications/1773PA3639.pdf> (Octobe 2011).

Ibarrola, R., Shackley, S., Hammond, J., 2012. Pyrolysis biochar systems for recovering biodegradable materials: a life cycle carbon assessment. Waste Manage. 32 (5), 859-868.

Islam, M.N., Ani, F.N., 2000. Techno-economics of rice husk pyrolysis, conversion with catalytic treatment to produce liquid fuel. Bioresource Technol. 73 (1), $67-$ 75.

Jirka, S., Tomlinson, T., 2014. 2013 State of the Biochar Industry. A Survey of Commercial Activity in the Biochar Field. International Biochar Initiative Report

Karve, P., Prabhune, R., 2009. Biochar for Carbon Reduction, Sustainable Agriculture and Soil Management (BIOCHARM). Final Report for APN Project ARCP200912NSY-Karve, Asia Pacific Network for Global Change Research, Pune, India <http://www.apn-gcr.org/resources/items/show/1563> (October 2011).

Lal, R., 2004. Soil carbon sequestration impacts on global climate change and food security. Science 304, 1623-1627.

Lehmann, J., Gaunt, J., Rondon, M., 2006. Bio-char sequestration in terrestria ecosystems - a review. Mitigat. Adapt. Strate. Global Change 11 (2), 395-419.

Li, A.M., Li, X.D., Li, S.Q., Ren, Y., Shang, N., Chi, Y., Yan, J.h., Cen, K.f., 1999. Experimental studies on municipal solid waste pyrolysis in a laboratory-scale rotary kiln. Energy 24 (3), 209-218.

Lundie, S., Peters, G.M., 2005. Life cycle assessment of food waste management options. J. Cleaner Product. 13 (3), 275-286.

Luske, B., van der Kamp, J., 2009. Carbon Sequestration Potential of Reclaimed Desert Soils in Egypt. Technical Report, Louis Bolk Institute \& Soil and More International.

Malkow, T., 2004. Novel and innovative pyrolysis and gasification technologies for energy efficient and environmentally sound MSW disposal. Waste Manage. 24 (1), 53-79.

Maraseni, T.N., 2010. Biochar: maximising the benefits. Int. J. Environ. Stud. 67 (3), 319-327.

Meyer, S., Glaser, B., Quicker, P., 2011. Technical, Economical, and Climate-Related Aspects of Biochar Production Technologies: A Literature Review. Environ. Sci. Technol. 45, 9473-9483.

Mohammed, Y.S., Mustafa, M.W., Bashir, N., 2013a. Status of renewable energy consumption and developmental challenges in Sub-Sahara Africa. Renew. Sust. Energy Rev. 27, 453-463.

Mohammed, Y.S., Mokhtar, A.S., Bashir, N., Saidur, R., 2013b. An overview of agricultural biomass for decentralized rural energy in Ghana. Renew. Sust. Energy Rev. 20, 15-25.

Nzila, C., Dewulf, J., Spanjers, H., Tuigong, D., Kiriamiti, H., van Langen, H., 2012. Multi criteria sustainability assessment of biogas production in Kenya. Appl. Energy 93, 496-506.

Ofori-Boateng, C., Lee, K.T. Mensah, M., 2013. The prospects of electricity generation from municipal solid waste (MSW) in Ghana: a better waste management option. Fuel Process. Technol. 110, 94-102.

Ofosu, M.A., Aklaku, E.D., 2010. Determining the optimum proportion of shea waste in anaerobic co-fermentation process. J. Sci. Technol. (Ghana) 30.

Ogawa, M., Okimori, Y., 2010. Pioneering works in biochar research, Japan. Soil Res. 48 (7), 489-500.

Peters, G.M., Rowley, H.V., 2009. Environmental comparison of biosolids management systems using life cycle assessment. Environ. Sci. Technol. 43 (8), 2674-2679.

Pratt, K., Moran, D., 2010. Evaluating the cost-effectiveness of global biochar mitigation potential. Biomass Bioenergy 34, 1149-1158.

Preston, T.R., Leng, R.A., 2013. The role of biochar in farming systems producing food and energy from biomass. In: Presented at the 4th International Conference On Sustainable Animal Agriculture For Developing Countries (SAADC2013] Lanzhou, pp. 89.

Puopiel, F., 2010. Solid Waste Management in Ghana, the Case of Tamale Municipal Area. Master thesis. Kwame Nkrumah University of Science and Technology, Kumasi, Ghana. 
Quaye, W., 2008. Food security situation in northern Ghana, coping strategies and related constraints. Afr. J. Agr. Res. 3 (5), 334-342.

Ringius, L., 2002. Soil carbon sequestration and the CDM: opportunities and challenges for Africa. Climatic Change 54 (4), 471-495.

Roberts, K.G., Gloy, B.A., Joseph, S., Scott, N.R., Lehmann, J., 2010. Life cycle assessment of biochar systems: estimating the energetic, economic, and climate change potential. Environ. Sci. Technol. 44, 827-833.

Salum, A., Hodes, G.S., 2009. Leveraging CDM to scale-up sustainable biogas production from sisal waste. In: Proceedings, pp. 2431-2442.

SARI, 2011. AGRA Soil Health Project, Annual Report 2010. Technical Report, Savannah Agricultural Research Institute, Nyankpala, Ghana.

Scholz, S., Sembres, T., Roberts, K., Whitman, T., Wilson, K., Lehmann, J., 2014 Biochar Systems for Smallholders in Developing Countries: Leveraging Current Knowledge and Exploring Future Potential for Climate-smart Agriculture. World Bank Publications.

Shackley, S., Carter, S., Knowles, T., Middelink, E., Haefele, S., Sohi, S., et al., 2012a Sustainable gasification-biochar systems? A case-study of rice-husk gasification in Cambodia, Part I: Context, chemical properties, environmental and health and safety issues. Energy Policy 42, 49-58.

Shackley, S., Carter, S., Knowles, T., Middelink, E., Haefele, S., Haszeldine, S., 2012b. Sustainable gasification-biochar systems? A case-study of rice-husk gasification in Cambodia, Part II: Field trial results, carbon abatement, economic assessment and conclusions. Energy Policy 41, 618-623.

Sonesson, U., Björklund, A., Carlsson, M., Dalemo, M., 2000. Environmental and economic analysis of management systems for biodegradable waste. Resour Conserv. Recy. 28 (1-2), 29-53.

Songsore, J., 1996. Population growth and ecological degradation in Northern Ghana: myths and realities. Inst. Africa Stud.: Res. Rev. 12 (1-2), 51-66.

Sparrevik, M., Field, J.L., Martinsens, V., Breedveld, G.D., Cornelissen, G., 2013. Life cycle assessment to evaluate the environmental impact of biochar implementation in conservation agriculture in Zambia. Environ. Sci. Technol. 47 (3), 1206-1215.

Sparrevik, M., Lindhjem, H., Andria, V., Fet, A.M., Cornelissen, G., 2014 Environmental and socioeconomic impacts of utilizing waste for biochar in rural areas in Indonesia - a systems perspective. Environ. Sci. Technol. 48, 4664-4671.
Sujana, I.P., Lanya, I., Subadiyasa, I.N.N., Suarna, I.W., 2014. The effect of dose biochar and organic matters on soil characteristic and corn plants growth on the land degraded by garment liquid waste. J. Biol. Agr. Healthcare 4, 77-88.

UNFCCC, 2010. Annex 18 - Methodological Tool "Tool to determine methane emissions avoided from disposal of waste at solid waste disposal site" (Version 05). In: Executive Board of the Clean Development Mechanism 55th Meeting Report, CDM Executive Board, Bonn.

UNFCCC, 2011. AMS-I.D.: grid connected renewable electricity generation, version 17.0. In: Executive Board of the Clean Development Mechanism 61st Meeting Report, CDM Executive Board, Bonn.

Vagen, T.G., Lal, R., Singh, B.R., 2005. Soil carbon sequestration in sub-Saharan Africa: a review. Land Degrad. Dev. 16 (1), 53-71.

Van der Voet, E., van Oers, L., Davis, C., Nelis, R., Cok, B., Heijungs, R., Chappin, E., Guinée, J.B., 2008. Greenhouse Gas Calculator for Electricity and Heat from Biomass. CML Rapport 179, Institute of Environmental Sciences (CML), Leiden University, Leiden, The Netherlands.

Verified Carbon Standard, 2013. Soil Carbon Quantification Methodology 1.0 <http://www.V-c-s.org/methodologies/VM0021> (February 2014).

Whitman, T., Lehmann, J., 2009. Biochar: one way forward for soil carbon in offset mechanisms in Africa? Environ. Sci. Policy 12 (7), 1024-1027.

Wikner, E., 2009. Modeling Waste to Energy systems in Kumasi, Ghana. MSc Thesis. Department of Energy and Technology, Swedish University of Agricultural Sciences, Uppsala, Sweden.

Woods, L., Cooper, J., 2006. Modelling Transport in LCA. Presentation at University of Washington, College of Engineering. <http://www.lcacenter.org/InLCA2006/ Woods-presentation.pdf>.

Woolf, D., Amonette, J.E., Street-Perrott, F.A., Lehmann, J., Joseph, S., 2010. Sustainable biochar to mitigate global climate change. Nature Commun. 1.

Yara Ghana, 2011. YaraMila UNIK 15 NPK 15-15-15 (Product Infosheet) <http:// www.yaraghana.com/Brochures/T15.aspx> (February 2012).

Yufeng, Z., Na, D., Jihong, L., Changzhong, X., 2003. A new pyrolysis technology and equipment for treatment of municipal household garbage and hospital waste. Renew. Energy 28 (15), 2383-2393.

Zurbrugg, C., Drescher, S., Sinha, M., Enaetullah, I., 2002. Decentralised composting in Dhaka, Bangladesh. Production of compost and its marketing. In: Proceedings of ISWA 2002 Annual Congress, Istanbul, Turkey, pp. 8-12. 